\title{
Phosphorus release during decomposition of the submerged macrophyte Potamogeton crispus
}

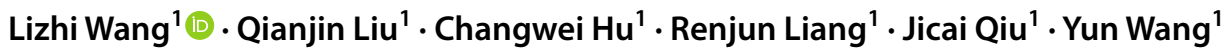

Received: 30 April 2017 / Accepted: 19 December 2017 / Published online: 18 January 2018

(c) The Author(s) 2018. This article is an open access publication

\begin{abstract}
The decomposition rate of Potamogeton crispus and its rates of phosphorus (P) release and sedimentation were quantified during natural senescence in a microcosm experiment. The decay of $P$. crispus was characterized by an exponential model with a mean mass loss coefficient $(k)$ of 0.05 day $^{-1}$. During the first 10 days, the rapid decomposition phase, $k$ was $0.068 \mathrm{day}^{-1}$. The rates of $\mathrm{P}$ release and total $\mathrm{P}$ sedimentation, as well as the dissolved total P, soluble reactive phosphorus, dissolved organic phosphorus, and particulate phosphorus, were quantified throughout the 30-day study period. The nitrogen $(\mathrm{N})$ and $\mathrm{P}$ contents of $P$. crispus increased whereas the carbon $(\mathrm{C})$ content and the C:N, C:P, and N:P ratios decreased near the end of the decomposition phase. In addition, the $\mathrm{pH}$, dissolved oxygen, and redox potential decreased during the rapid release of $\mathrm{P}$. The results indicated that the rate of mass loss was slower from dried plants than from senescent plants. The rapid decomposition rate, which was associated with a high rate of $\mathrm{P}$ release, suggests that much of the accumulated $\mathrm{P}$ will eventually be returned to the aquatic ecosystem. These data illuminate the mechanisms of decomposition and suggest a strategy of reducing eutrophication by harvesting $P$. crispus prior to its senescence.
\end{abstract}

Keywords Phosphorus $\cdot$ Submerged macrophyte $\cdot$ Potamogeton crispus $\cdot$ Decomposition

\section{Introduction}

Submerged macrophytes are a vital part of shallow lake ecosystems. They occupy the entire water column, from the bottom to the surface of a shallow lake. These plants convert sunlight into energy and make chemical elements bioavailable, allowing them to be absorbed by other plants (Qin 2009; Yu et al. 2010). They play an important role in phosphorus (P) cycling, especially in shallow lakes. They are very active recyclers of sediment $P$ and should be viewed as potential P pumps (Carignan and Kalff 1980). They also have many other important ecological functions, such as improving dissolved oxygen (DO) content in the environment and changing the oxidation reduction potential (ORP) and $\mathrm{pH}$ of the

Handling Editor: Tomomi Inoue.

Lizhi Wang

wanglizhi@lyu.edu.cn

1 Shandong Provincial Key Laboratory of Water and Soil Conservation and Environmental Protection, College of Resources and Environment, Linyi University, Linyi 276005, China water and sediments through photosynthesis (Moss 1990). They are primarily responsible for the maintenance of clear water in shallow lakes, and they often affect the functioning of the entire lake's ecosystem (Scheffer and Jeppesen 2007).

During the growth period of submerged macrophytes, they can accumulate nutrients from both water and sediments. However, when submerged macrophytes die and decompose, photosynthetic production of oxygen ceases and organic matter and nutrients are released back into the aquatic environment. Bacteria and fungi that decompose decaying plant material in turn consume DO for respiration. Therefore, the control and management of submerged macrophytes are very important, especially after they have been restored in a lake ( $\mathrm{Li}$ et al. 2014). The decomposition of aquatic macrophytes can substantially influence the long-term recycling of nutrients in freshwater ecosystems (Carpenter and Lodge 1986; Webster and Benfield 2003).

$\mathrm{P}$ present in water can be categorized into particulate phosphorus (PP) and dissolved total phosphorus (DTP). DTP can be subdivided into dissolved organic phosphorus (DOP) and soluble reactive phosphorus (SRP) (Jarvi et al. 2002). SRP is the most abundant form and the one most widely measured in natural waters, and it can be used by plants 
directly. DOP can play an important role in biological and biogeochemical processes. Previous studies have reported that phytoplankton are capable of assimilating P from the organic fraction, and DOP is reported to contribute a significant fraction of the DTP in natural waters, particularly where there is biological activity (Yoshimura et al. 2007). PP plays an important role in the change between different $P$ fractions. In addition to containing orthophosphate, which can be directly absorbed and used by submerged macrophytes, it can transform into a type of dissolved $\mathrm{P}$ or be absorbed by the sediments (Gao et al. 2009).

The decomposition of submerged macrophytes is a complex process that is mediated by microorganisms. During the early decay phase of macrophytes, the leaching of watersoluble substances plays a key role in the loss of litter mass (Varga 2003). The rapid release of phosphorus accompanies this leaching. The amount of dissolved phosphorus released from plant cells into the water column increases rapidly during the first few days. $\mathrm{P}$ concentrations in the water reach their maximum value after about 15 days and subsequently decrease gradually over time (Carvalho et al. 2015; Chimney and Pietro 2006). During plant decomposition, hardly any gaseous phosphorus is released (Boulton and Boon 1991). Therefore, the released $\mathrm{P}$ must sink to the sediment at the bottom. During the decomposition phase of macrophytes, sediments and plant detritus absorb P simultaneously at an unknown rate. Little is known about the role that plant detritus plays in the stabilization of $\mathrm{P}$ during the decomposition of macrophytes in shallow lakes. Although it is known that sediments (containing detritus) play a predominant role in the decrease of $\mathrm{P}$ during the end of the decay phase of macrophytes (Juston et al. 2012), there is little information about the importance of detritus in $\mathrm{P}$ cycling during the decomposition of macrophytes in shallow lakes.

There have been numerous recent studies of $\mathrm{P}$ release during the decay phase of submerged macrophytes in natural and constructed wetlands (Asaeda et al. 2000; Titus and Pagano 2002; Wrubleski et al. 1997). Most of these studies use the litter bag technique to measure the rate of macrophyte decomposition. Using this technique, macrophytes are collected from the study area and dried at $60{ }^{\circ} \mathrm{C}$ or air-dried to constant mass and placed in plastic bags. If the macrophytes are large plants, such as Phragmites australis, they are usually fragmented to a coarse litter containing natural proportions of stems and leaves (Ágoston-Szabó et al. 2006; Longhi et al. 2008). Decomposition rates are estimated with an exponential model (Olson 1963):

$W_{t}=W_{0} \mathrm{e}^{-k t}$,

where $t$ is the time (in days) since the start of the experiment, $W_{t}$ is the dry mass of litter remaining at time $t(\%), W_{0}$ is the initial dry mass of litter at time 0 (defined as $100 \%$ ), and $k$ is the decomposition rate coefficient $\left(\mathrm{day}^{-1}\right)$.
We determined that the litter bag technique cannot effectively estimate the rate of macrophyte decomposition. Only part of the plant cell dies during decomposition, and generally the decomposition progresses from the leaves to the stem. The litter bag technique assumes that all plant cells die at the beginning of the decomposition phase (Smock and Stoneburner 1980), so the decomposition rate that it generates may not be accurate.

In the present study, we evaluated the decomposition process for Potamogeton crispus in a microcosm. The aim of the study was to determine the decomposition rate of $P$. crispus during natural senescence and to gain insights into the cycling of $\mathrm{P}$ between water and P. crispus.

\section{Materials and methods}

\section{Study area}

Aboveground parts of the submerged macrophyte, $P$. crispus, were collected from Lake Yimeng in Linyi in China $\left(35^{\circ} 05^{\prime} \mathrm{N}, 118^{\circ} 19^{\prime} \mathrm{E}\right)$ at the beginning of the decomposition season. Lake Yimeng was formed in 1997 when a rubber dam $(1135 \mathrm{~m})$ was built across the Yi River, capturing about $17 \mathrm{~km}^{2}$ of water. In recent decades, the lake has exhibited dense canopy-forming populations of P. crispus, which covers nearly $90 \%$ of the lake during the spring and summer. Different types of management have been applied to reduce algal blooms (eutrophication), including harvesting $P$. crispus in summer and applying algaecides. However, in recent years, the lake has exhibited severe algal blooms in both summer and early autumn (Fig. 1).

The amount of $\mathrm{P}$ loading from the surrounding watershed was $90.31 \mathrm{t}$ each year (Linyi Hydrological Bureau 2016; Wang et al. 2007). The average biomass of P. crispus was $7.98 \mathrm{~kg} \mathrm{~m}^{-2}$; therefore, the estimated maximum amount of P stored in P. crispus was $39.07 t\left(2.55 \mathrm{~g} \mathrm{~m}^{-2}\right)$ in this lake. P. crispus stored $43.26 \%$ of the $\mathrm{P}$ in the lake. Almost all of the $\mathrm{P}$ was released back into the water during the decomposition period, and only a few aquatic plants (e.g., Nymphoides peltata and Trapa bispinosa) grew in this period, covering about $5 \%$ of the lake area. The decomposition of P. crispus may be one of the important triggers for algal blooms in this lake. The average TP concentration was $0.13 \mathrm{mg} \mathrm{L}^{-1}$ from March to June, which is the growth period of P. crispus, and it was $0.56 \mathrm{mg} \mathrm{L}^{-1}$ from July to September, which is the decomposition period of P. crispus.

\section{Experimental microcosm}

In order to determine the rate of $\mathrm{P}$ released by $P$. crispus during decomposition, plants were collected from different sites in Lake Yimeng on May 15-16. Plant materials were 


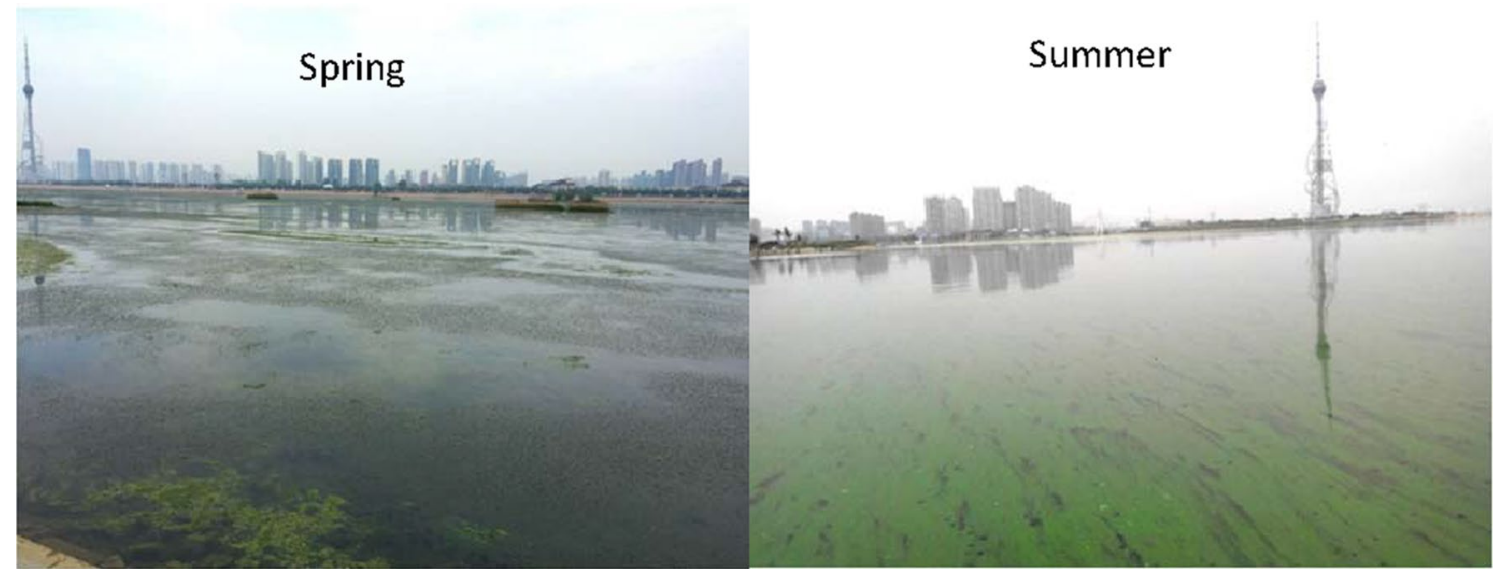

Fig. 1 Lake Yimeng: Potamogeton crispus in spring; algal blooms after the death of P. crispus in summer

partially living at the beginning of the experiment. As the vegetation was heterogeneously distributed in the lake, subsamples were randomly taken from different parts of the lake. The samples covered the center (depth 1.5-2.3 m), the shore (depth 1-1.3 m), and the southern and northern parts. In each sample site, the sampling area was delimited using a polyvinyl chloride tube (area $0.50 \mathrm{~m}^{2}$ ), and completely submerged macrophytes were collected from the boat. A rake was used to remove plants from the bottom, collecting both aboveground and belowground biomass (AGB and $\mathrm{BGB}$, respectively). In order to determine the ratio of $\mathrm{BGB}$ to AGB, the weights of BGB (root and rhizome) and AGB (stem, turion, and leaf) of $P$. crispus were recorded for each plant. The average ratio of BGB to AGB was $0.059 \pm 0.04$ (dry weight). Because BGB made a very low contribution to total biomass, and as it was difficult to collect all the parts of P. crispus from the lake bottom, only the AGB of P. crispus was used in the microcosm experiments. Most of the AGB of P. crispus breaks off from the root when it begins to decompose at the end of the growing season. Therefore, in the present experiment, only the aboveground portion was used to simulate the course of decomposition.

Harvested P. crispus was incubated with lake water in a tank for less than 1 day before the adherent materials were removed. Then the plant materials were gently rinsed with tap water and distilled water to remove sediment and periphyton. P. crispus was divided into 99 parts, each with a fresh weight of $100 \mathrm{~g}$. Each fresh sample of P. crispus was placed in a beaker $(4 \mathrm{~L})$, to which was added $3.5 \mathrm{~L}$ deionized water. The system simulated the decomposition course of $P$. crispus in still water with no circulation. The decomposition experiment proceeded in an incubator with a stable temperature of $25{ }^{\circ} \mathrm{C}\left( \pm 3{ }^{\circ} \mathrm{C}\right)$. The light intensity was $800 \pm 50 \mu \mathrm{mol} \mathrm{m}^{-2} \mathrm{~s}^{-1}$ (photoperiod 12:12 h light:darkness). The experiment spanned 30 days. Each day, three breakers were collected and the biomass (fresh weight and dry weight) and $\mathrm{P}$ concentrations in water and plant material were recorded. The values of fresh weight, dry weight, and $\mathrm{P}$ concentration in water and plants reported here are the means of triplicate samples. The remaining mass (\%) is based on the dry weight.

\section{Water and plant analyses}

The pH (PHSJ-4A, Lei-ci, Shanghai, China), ORP (Lei-ci), and DO in the overlying water (5750, YSI, Yellow Springs, $\mathrm{OH}, \mathrm{USA}$ ) were measured first.

Next, 10-mL water samples were removed from the three beakers that were collected daily and stored in a refrigerator at $4{ }^{\circ} \mathrm{C}$ until TP, PP, DTP, DOP, and SRP analysis. The methods are summarized below. For TP analysis, the water sample was autoclaved at $121{ }^{\circ} \mathrm{C}$ for $30 \mathrm{~min}$ after $\mathrm{K}_{2} \mathrm{~S}_{2} \mathrm{O}_{8}$ was added. Thereafter, $10 \%$ ascorbic acid was added, and the sample was measured using the molybdenum blue spectrophotometric method. A continuous flow analyzer (Flowsys III, Systea Company, Anagni, Italy) was used to determine the $\mathrm{P}$ concentration. The same method was used for the SRP determination, except that the water sample was filtered through a $0.45-\mu \mathrm{m}$ cellulose acetate membrane and not autoclaved. DTP was measured using the same method as that employed for TP, but again the water was filtered through a $0.45-\mu \mathrm{m}$ cellulose acetate membrane. The difference between TP and DTP was defined as the sum of the PP fraction. The difference between DTP and SRP was defined as the sum of the DOP fraction. The detection limit for SRP and DTP concentrations in the overlying water was $1 \mu \mathrm{g} \mathrm{L}^{-1}$. All materials used for these analyses were purchased from Shanghai N\&D Co. Ltd. (Shanghai, China). For all samples, triplicates were analyzed, and the data are expressed as the mean.

An appropriate amount of deionized water was then added to other beakers to compensate for the loss of water 
through evaporation every 10 days. The following equation was used to calculate the $\mathrm{P}$ concentration:

$c_{n}=\frac{c_{n}^{\prime} v}{v+v_{n}}$,

where $C_{n}$ is the actual $\mathrm{P}$ concentration at the $n$-th sampling time, $c_{n}^{\prime}$ is the measured $\mathrm{P}$ concentration before adding deionized water, $v$ is the volume of overlying water before adding deionized water, and $v_{n}$ is the volume of deionized water added at time $n$.

Water samples were siphoned from approximately $10 \mathrm{~cm}$ below the surface of the beakers (i.e., around the middle of the beakers). The samples were kept at $0-4{ }^{\circ} \mathrm{C}$ and $\mathrm{P}$ was analyzed within $24 \mathrm{~h}$ of sampling.

P. crispus from each beaker was oven-dried at $85-90{ }^{\circ} \mathrm{C}$ and maintained in an air-circulating oven for approximately 2 weeks until it achieved a constant dry weight (DW). The dry material was ground and stored in vacuum-sealed bags at room temperature. The concentrations of $\mathrm{P}$, nitrogen $(\mathrm{N})$, and carbon $(\mathrm{C})$ in plant material were determined by standard methods (Sommers 1977).

\section{Data analysis}

The results are presented as averages of triplicates. The significance of treatment effects was determined at the 0.05 probability level. SPSS 16.0 and SigmaPlot 12.5 were used for model analyses. The mass loss coefficient $(k)$ was calculated for a whole period, based on the exponential decay model (Eq. 1).

\section{Results}

\section{Mass loss and $P$ concentration in plants}

The mass loss coefficient $k$, based on the exponential decay model (Eq. 1), was $0.05 \mathrm{day}^{-1}$. P. crispus retained $22.00 \%$ (all dead material) of its original weight after 30 days of incubation. The mass changed rapidly in the first 10 days (declining to $50.00 \%$ of the original mass, with partially living material) and changed slowly in the last 20 days (from 50.00 to $22.00 \%$ of the original mass).

Therefore, the first 10 days appear to be the rapid decomposition phase, whereas the last 20 days represent the slow decomposition phase (Fig. 2). Variation in the P concentration in P. crispus was observed during decomposition (Fig. 2). The $\mathrm{P}$ concentration in P. crispus detritus increased
Fig. 2 Phosphorus $(\mathrm{P})$ concentration (mean $\pm \mathrm{SD})$ in plants and the mean $( \pm \mathrm{SD})$ percentage of Potamogeton crispus mass remaining after decomposition during the study period

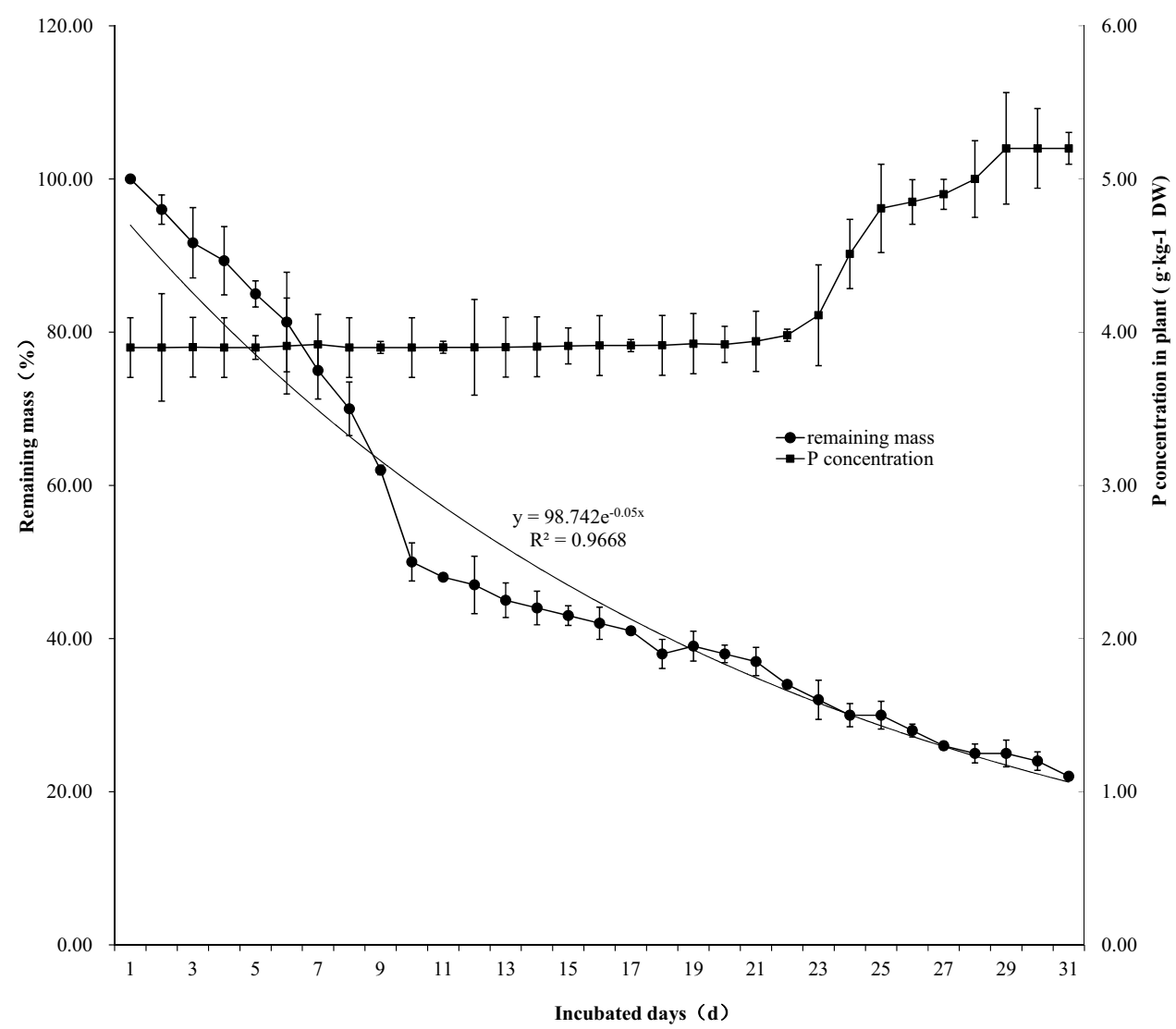


slowly during the first 22 days (from 3.90 to $3.98 \mathrm{~g} \mathrm{~kg}^{-1}$ DW), but accelerated starting on day 23. After $30 \mathrm{~d}$ of incubation, the $\mathrm{P}$ concentration in $P$. crispus detritus was $5.20 \mathrm{~g} \mathrm{~kg}^{-1}$.

\section{$P$ concentration in water}

The changes in $\mathrm{P}$ concentration in water during decomposition are shown in Fig. 3. TP, DTP, and SRP increased quickly during the first 15 days and decreased slowly from day 16. On the 10th day of the decomposition experiment, the concentrations of TP, DTP, and SRP were 6.32, 5.60, and $4.48 \mathrm{mg} \mathrm{L}^{-1}$, respectively. By the end of the experiment, TP, DTP, and SRP reached 5.57, 5.10, and $4.13 \mathrm{mg} \mathrm{L}^{-1}$, respectively. Therefore, the first 10 days constitute a period of rapid $\mathrm{P}$ release, whereas days $10-15$ represent a period of slow P release. Compared with TP, the DTP and SRP concentrations of DOP and PP remained at low levels (DOP $0-1.12 \pm 0.06 \mathrm{mg} \mathrm{L}^{-1}$, PP $0-1.81 \pm 0.02 \mathrm{mg} \mathrm{L}^{-1}$ ). DOP and $\mathrm{PP}$ increased slowly during the decomposition phase, after which DOP showed a slight decrease, starting on day 15 . The maximum values of the different $P$ fractions in water could be ordered as follows: DTP $>$ SRP $>$ PP $>$ DOP.

In this experiment, $\mathrm{P}$ release occurred from the beginning to the maximum value of $\mathrm{P}$, and the $\mathrm{P}$ sedimentation phase occurred from the maximum value of $P$ to the end of the experiment. The $\mathrm{P}$ release rates of TP, DTP, SRP, DOP, and $\mathrm{PP}$ were $0.1389 \pm 0.0021,0.1307 \pm 0.0020,0.1045 \pm 0.0011$, $0.0261 \pm 0.0008$, and $0.0253 \pm 0.0015 \mathrm{mg} \mathrm{day}^{-1} \mathrm{~g}^{-1}$, respectively (based on the dry detritus weight recorded at the beginning of the experiment). The $\mathrm{P}$ sedimentation rates of TP, DTP, SRP, DOP, and PP were $0.0641 \pm 0.0031$, $0.0700 \pm 0.0028,0.0597 \pm 0.0013,0.0081 \pm 0.0010$, and $0.0013 \pm 0.0001 \mathrm{mg} \mathrm{day}^{-1} \mathrm{~g}^{-1}$, respectively (based on the dry detritus weight recorded at the beginning of the experiment).

The various phosphorus fractions and environmental factors were correlated (Table 1). TP, DTP, SRP, and DOP were negatively correlated with the environmental factors $\mathrm{pH}, \mathrm{DO}$, and ORP. PP was negatively correlated with $\mathrm{pH}$ and DO but weakly positively correlated with ORP, TP, DTP, SRP, and DOP. In addition, TP, DTP, SRP, DOP, and PP were negatively correlated with the amount of mass remaining.

The nitrogen concentration in P. crispus decreased quickly during the first few days (from the 1st to the 9th day) and gradually increased at the end of the experiment (to $31.53 \pm 0.63 \mathrm{~g} \mathrm{~kg}^{-1}$ on the 31 st day). The carbon concentration in $P$. crispus remained stable from the 1 st day to the 20th day, but decreased from day 21 , to reach $370.00 \pm 18.5 \mathrm{~g} \mathrm{~kg}^{-1}$ at the end of the experiment (Fig. 4).

All $\mathrm{P}$ concentrations in water increased to the maximum value and then decreased gradually with time. A peak equation (Wang 2015) was used to describe the changes in P concentration in water:

$P_{t}=\frac{a}{t} \mathrm{e}^{\left[-0.5\left(\frac{\ln (t / k)}{b}\right)^{2}\right]}$,

where $t$ is the time (in days) since the start of the experiment, $P_{t}$ is the $\mathrm{P}$ concentration in water at time $t\left(\mathrm{mg} \mathrm{L}^{-1}\right)$, and $a$, $k$, and $b$ are constants.
Fig. 3 The phosphorus (P) concentrations (mean $\pm \mathrm{SD})$ in water, including total P (TP), dissolved total P (DTP), particulate phosphorus (PP), soluble reactive phosphorus (SRP), and dissolved organic phosphorus (DOP)

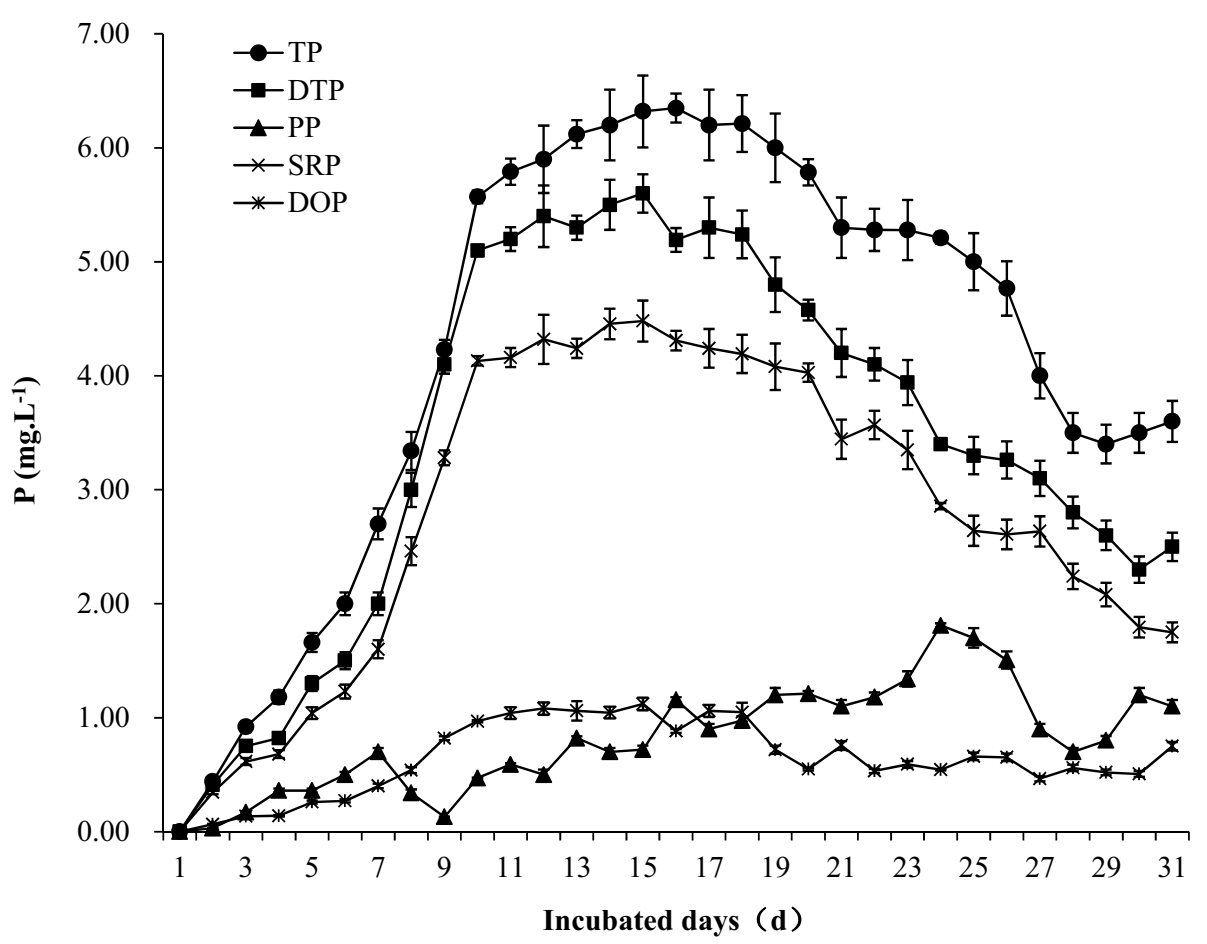


Table 1 Pearson correlation coefficients between various phosphorus fractions and environmental factors

\begin{tabular}{|c|c|c|c|c|c|c|c|c|c|}
\hline & $\mathrm{TP}$ & DTP & SRP & DOP & $\mathrm{PP}$ & $\mathrm{pH}$ & DO & ORP & $\begin{array}{l}\text { Remain- } \\
\text { ing } \\
\text { mass }\end{array}$ \\
\hline TP & 1 & & & & & & & & \\
\hline DTP & $0.974 * *$ & 1 & & & & & & & \\
\hline SRP & $0.975 * *$ & $0.997 * *$ & 1 & & & & & & \\
\hline DOP & $0.902 * *$ & $0.943 * *$ & $0.914 * *$ & 1 & & & & & \\
\hline PP & $0.590 * *$ & $0.393^{*}$ & $0.408 *$ & 0.301 & 1 & & & & \\
\hline $\mathrm{pH}$ & $-0.539 * *$ & $-0.379 *$ & $-0.387^{*}$ & -0.32 & $-0.841 * *$ & 1 & & & \\
\hline DO & $-0.805^{* *}$ & $-0.817 * *$ & $-0.834 * *$ & $-0.688^{* *}$ & $-0.356^{*}$ & 0.134 & 1 & & \\
\hline ORP & $-0.527 * *$ & $-0.663 * *$ & $-0.642 * *$ & $-0.708 * *$ & 0.229 & -0.3 & $0.633 * *$ & 1 & \\
\hline Remaining mass & $-0.732 * *$ & $-0.613 * *$ & $-0.609 * *$ & $-0.589 * *$ & $-0.792 * *$ & $0.917 * *$ & 0.321 & 0.049 & 1 \\
\hline
\end{tabular}

$T P$ total phosphorus, DTP dissolved total phosphorus, $S R P$ soluble reactive phosphorus, DOP dissolved organic phosphorus, $P P$ particulate phosphorus, $D O$ dissolved oxygen, $O R P$ oxidation reduction potential

* Correlation is significant at the 0.05 level (two-tailed)

** Correlation is significant at the 0.01 level (two-tailed)

Fig. 4 The nitrogen and carbon concentrations (mean $\pm \mathrm{SD})$ in Potamogeton crispus during the study period

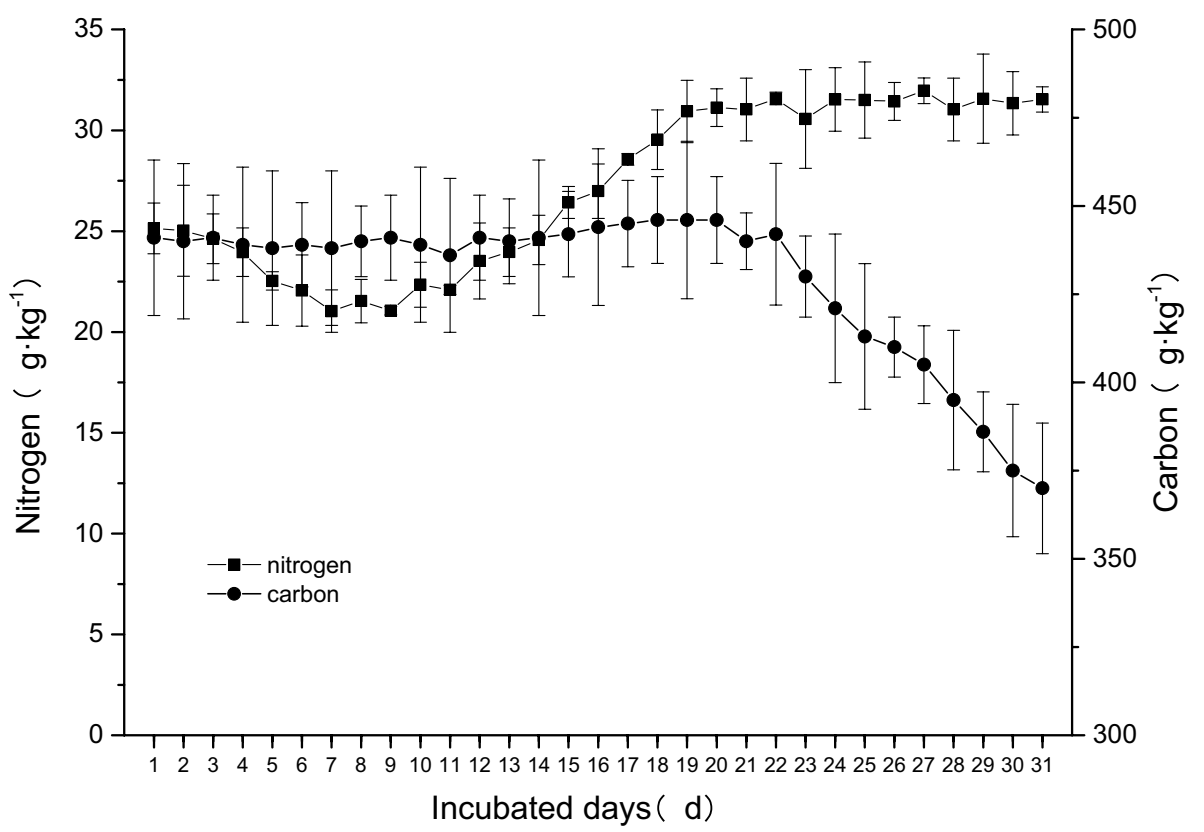

Values of the regression coefficient of determination for and the constants in Eq. 3 are shown in Table 2. TP, DTP, SRP, DOP, and PP had high values of $R^{2}$. These high $R^{2}$ values suggest that they can be used to predict a model of $P$ release during $P$. crispus decomposition.

\section{Environmental factors in the experiment}

The environmental factors in the water changed over time as decomposition progressed. ORP and DO decreased quickly during the first few days and gradually increased at the end of the experiment, whereas $\mathrm{pH}$ gradually decreased during
Table 2 Values of the regression coefficient of determination for and the constants in Eq. 2

\begin{tabular}{lrrrrr}
\hline & \multicolumn{1}{l}{ TP } & DTP & \multicolumn{1}{c}{ SRP } & \multicolumn{1}{c}{ DOP } & \multicolumn{1}{c}{ PP } \\
\hline$a$ & 117.94 & 92.72 & 76.12 & 16.67 & 48.29 \\
$b$ & 0.63 & 0.57 & 0.57 & 0.59 & 0.86 \\
$k$ & 22.75 & 19.77 & 19.80 & 19.51 & 58.19 \\
$R^{2}$ & 0.98 & 0.98 & 0.99 & 0.85 & 0.70 \\
\hline
\end{tabular}

TP total phosphorus, DTP dissolved total phosphorus, SRP soluble reactive phosphorus, $D O P$ dissolved organic phosphorus, $P P$ particulate phosphorus 
the course of the experiment (Fig. 5). The temperature remained stable at approximately $25^{\circ} \mathrm{C}$. The $\mathrm{pH}$ gradually decreased from neutral $(7.10 \pm 0.35)$ at the beginning of the experiment to slightly acidic values $(6.10 \pm 0.31)$ at the end. ORP decreased quickly during the first few days, reaching $-110.0 \pm 2.2 \mathrm{mV}$ on day 9 . ORP increased gradually to $22.5 \pm 1.3 \mathrm{mV}$ on day 25 and then remained stable, followed by a slight decrease to $12.1 \pm 0.6 \mathrm{mV}$ by the end of the experiment. DO decreased quickly over the first few days, reaching $1.01 \pm 0.21 \mathrm{mg} \mathrm{L}^{-1}$ on day 13 . After that it remained stable, and then it increased from day 24 , reaching $5.02 \pm 0.25 \mathrm{~m} \mathrm{~L}^{-1}$ by the end of the experiment.

\section{Discussion}

The final decomposition rates measured for $P$. crispus differed from those reported in other studies that examined the decomposition of dried plants, such as $k=0.0205$ day $^{-1}$ in Howard-Williams and Davies (1979). Our results were closest to those reported by Rogers and Breen (1982); i.e., $k=0.04 \mathrm{day}^{-1}$ for natural senescence and $k=0.02 \mathrm{day}^{-1}$ for dry materials. Moreover, the decomposition rates of $P$. crispus from the present study differed from those of other species of Potamogeton, including decomposition rates of 0.01 day $^{-1}$ reported for P. maackianus (Xie et al. 2004) and 0.019 day $^{-1}$ for P. pectinatus (Carvalho et al. 2015). The decay rate for each species showing uniform exponential decay can be calculated as a constant for the whole decay period from Eq. 1. The results of this comparison are shown in Table 3. The overall rate of mass loss was slower from dried P. crispus than from senescent plants.
P. crispus is distributed in a wide range of climatic regions. It can tolerate hypertrophic conditions and grows well in polluted water (Heuschele and Gleason 2014). $P$. crispus plays a central role in aquatic ecosystems by helping in the regulation of nutrient levels, including $\mathrm{P}$. The growth of $P$. crispus can lead to $\mathrm{P}$ and $\mathrm{N}$ depletion and decreased chemical oxygen demand, along with increased water transparency and DO in the water column (Bakker et al. 2010). These characteristics make it a suitable candidate for bioremediation of polluted waters, especially in shallow lakes (Leoni et al. 2015). Previous studies indicated that $P$. crispus has the capacity to regulate nutrients in shallow lakes by absorbing large amounts of nutrients.

Our results showed that $P$. crispus had a high degradation rate. Field monitoring of Lake Yimeng showed that the TP concentration increased from April to June, reaching an average concentration of $0.27 \pm 0.02 \mathrm{mg} \mathrm{L}^{-1}$ in June (Fig. 6). The highest TP concentration was lower than that in our microcosm experiment. $\mathrm{P}$ absorption by sediments, algae utilization of $\mathrm{P}$, and harvesting of $P$. crispus may be the main underlying reasons for this. The TP concentration of Lake Yimeng decreased in July because water levels were high during the rainy season. The high rates of degradation found in our experiment indicate that this plant plays an important role in nutrient dynamics in the lake studied.

Several factors affect the rate of degradation of aquatic macrophytes in lentic environments, including the chemical composition of the plant and the activity of the microbial decomposer community (Gessner 2000). Detritus with high $\mathrm{N}$ and $\mathrm{P}$ concentrations and a low $\mathrm{C}$ concentration has low $\mathrm{C}: \mathrm{N}$ and $\mathrm{C}: \mathrm{P}$ ratios and is considered good-quality detritus. König et al. (2013) studied leaf breakdown for different macrophytes in a subtropical stream and reported that those
Fig. 5 The temperature $(T), \mathrm{pH}$, oxidation reduction potential (ORP), and dissolved oxygen (DO) (mean $\pm \mathrm{SD})$ in water during the study period

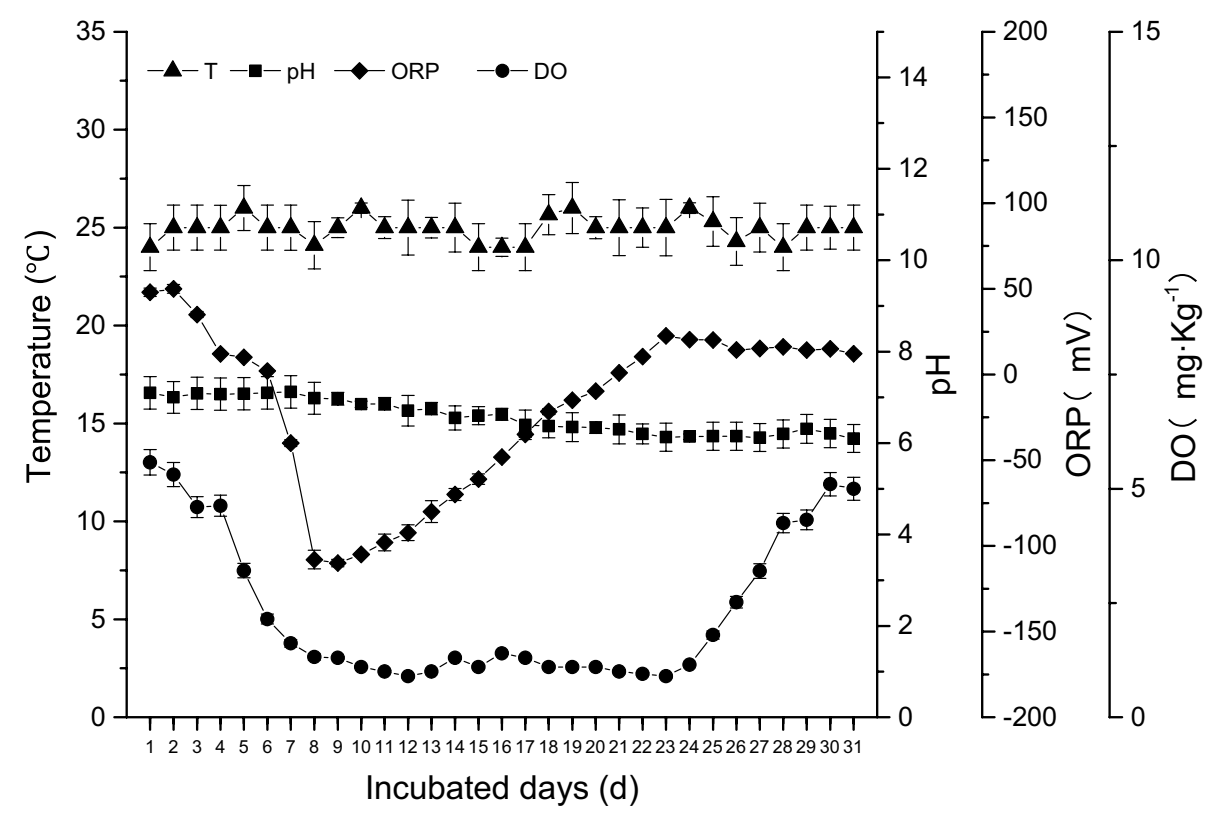




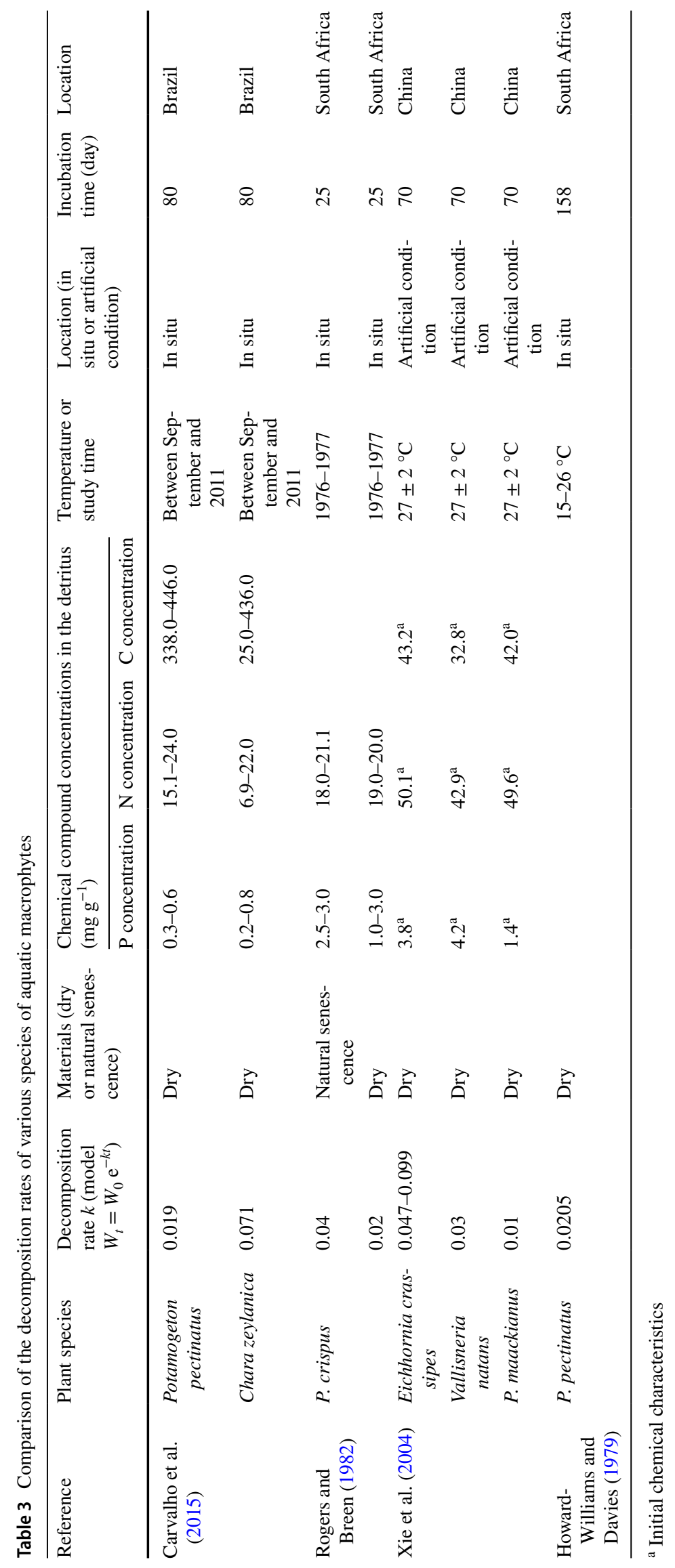




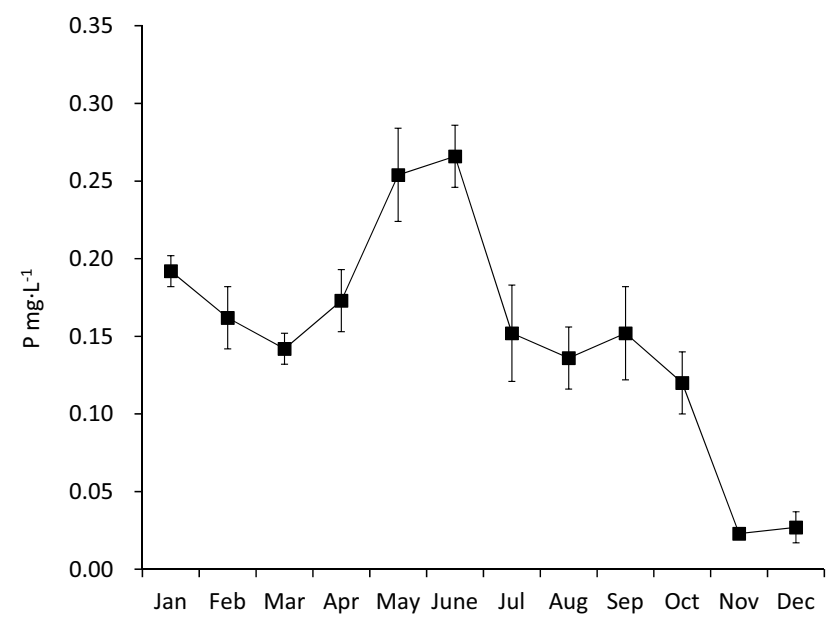

Fig. 6 The TP concentrations (mean \pm SD) in Lake Yimeng over the course of a year $(n=12)$

with a higher nutritional content might be more palatable to scavengers, which would positively influence the rate of tissue degradation.

Our results showed that the $\mathrm{N}$ and $\mathrm{P}$ contents increased and the $\mathrm{C}$ content decreased by the end of the decomposition phase (Figs. 2, 5). The increase in the $\mathrm{P}$ content is generally attributed to uptake by decomposer microbes associated with the plant tissue and net $\mathrm{P}$ immobilization by the decomposing plant tissue (Gonçalves et al. 2004). At the end of the experiment, the plant detritus could be categorized into a larger plant detritus part and a flocculation part. Only the larger detritus part was analyzed. The flocculation part included sedimentary $\mathrm{P}$ and other $\mathrm{P}$ fractions; this part of the $\mathrm{P}$ was equivalent to the whole $\mathrm{P}$ minus the $\mathrm{P}$ in water and the larger plant detritus (Fig. 7). The percentages of $\mathrm{P}$ in water, the larger plant detritus, and the flocculation part corresponded to $32.30,29.34$, and $38.36 \%$ of the total, respectively, at the end of the experiment. These results are similar to those of other studies of macrophyte decomposition in lakes (Byren and Davies 1986; Chimney and Pietro 2006; Wrubleski et al. 1997).

The increased $\mathrm{N}$ and $\mathrm{P}$ concentrations and decreased $\mathrm{C}$ concentration in the detritus led to low $\mathrm{C}: \mathrm{N}$ and $\mathrm{C}: \mathrm{P}$ ratios by the end of the decomposition phase. Menendez et al. (2004) reported that plant material with a higher nutritional content might be more palatable to scavengers. $\mathrm{C}: \mathrm{N}$ and $\mathrm{C}: \mathrm{P}$ ratios are considered to be two important factors affecting microbial activity and population dynamics, in particular by inhibiting the immobilization of $\mathrm{N}$ and $\mathrm{P}$ by microorganisms (Dahroug et al. 2016). Studies of submerged macrophytes in lakes have shown that the decomposition rate is mainly associated with the bacterial community (Millelindblom and Tranvik 2003). The reductions in C:N, C:P, and N:P (Fig. 8) in the present study revealed an increase in nutritional quality during decomposition. The regulation of nutrient balance by $P$. crispus depends on its life stage (growth vs. senescence). P. crispus plays a double role with respect to the
Fig. 7 The percentages of phosphorus $(\mathrm{P})$ in water, plants, and sediments and other fractions

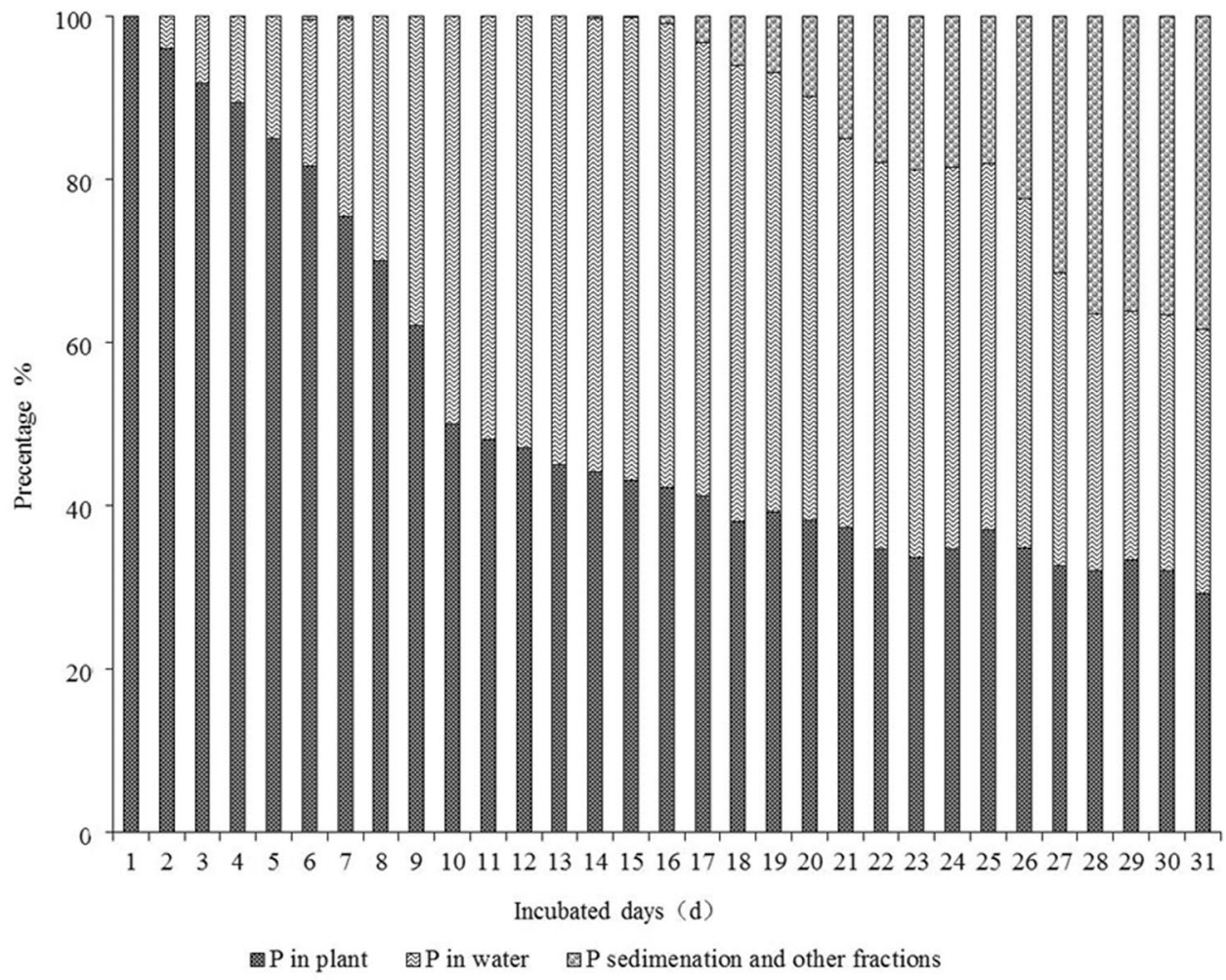


Fig. 8 The carbon:nitrogen (C:N), carbon:phosphorus $(\mathrm{C}: \mathrm{P})$, and nitrogen:phosphorus $(\mathrm{N}: \mathrm{P})$ ratios, based on mean values of C, N, and P in Potamogeton crispus plants during the study period

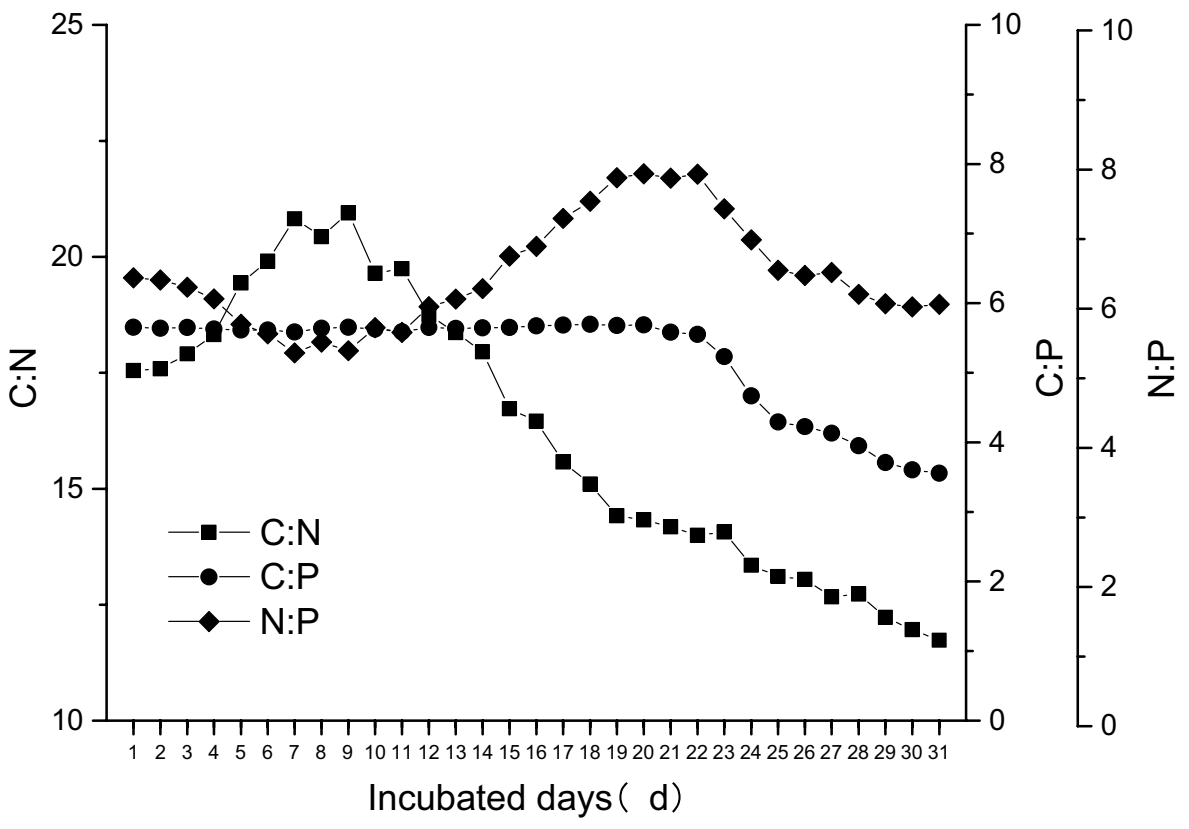

$\mathrm{P}$ cycle and may act as a nutrient sink (Siong and Asaeda 2006).

The relatively high water temperature $\left(25 \pm 1{ }^{\circ} \mathrm{C}\right)$ probably accelerated the decomposition of the vegetation, causing decreases in the DO, pH, and ORP of water (Fig. 4) that coincided with $P$ release (Asaeda et al. 2000).

The sharp increase in the $\mathrm{P}$ content of $P$. crispus during the first 10 days of decomposition suggests higher internal $\mathrm{P}$ loading via release through submerged macrophytes (Kröger et al. 2007). The majority of the $\mathrm{P}$ released from plants (approximately 80\%) occurs in soluble form. Thus, the major $\mathrm{P}$ pathway is from the sediments to the water via macrophytes. This hypothesis was confirmed by our results, which showed that the physical leaching of $P$ from plant tissue occurred during the early stages of senescence.

Our results indicated that the $\mathrm{P}$ concentrations in the overlying water mainly depend on the plant $\mathrm{P}$ content and developmental stage. $P$. crispus removes $\mathrm{P}$ from the water and sediment during its growth period; however, the rapid decomposition rates suggest that much of the accumulated nutrients will eventually be returned to the water ecosystem. Therefore, the harvesting of $P$. crispus prior to its senescence may significantly reduce the internal $\mathrm{P}$ load (Bennett et al. 2001). Furthermore, the management of $P$. crispus by other means, such as the application of algaecides, could reduce the occurrence and intensity of algal blooms (Boström et al. 1988).

\section{Conclusion}

We measured decomposition rates of and $\mathrm{P}$ release from the submerged macrophyte $P$. crispus in a microcosm experiment. Using the exponential decay model, the $P$. crispus mass loss coefficient $k$ was found to be 0.05 day $^{-1}$ under conditions of natural senescence. All P fractions in water reached a maximum value and then decreased gradually. The maximum values of the different fractions in water could be ordered as follows: DTP $>$ SRP $>$ PP $>$ DOP.

$\mathrm{P}$ was released from the beginning of the present experiment until it reached its maximum value. Thereafter, $\mathrm{P}$ was absorbed until the end of the experiment. The $\mathrm{P}$ release rate of TP was $0.1389 \pm 0.0021 \mathrm{mg} \mathrm{day}^{-1} \mathrm{~g}^{-1}$, and the P sedimentation rate of TP was $0.0641 \pm 0.0031 \mathrm{mg} \mathrm{day}^{-1} \mathrm{~g}^{-1}$.

The environmental factors $\mathrm{pH}, \mathrm{DO}$, and ORP declined along with the rapid $\mathrm{P}$ release. The $\mathrm{P}$ and $\mathrm{N}$ contents in water had increased by the end of the experiment, whereas the $C: N, C: P$, and $N: P$ ratios had decreased. The high $\mathrm{N}$ and $\mathrm{P}$ concentrations and the low $\mathrm{C}$ concentration of $P$. crispus are the main reason for the rapid decomposition.

Our findings provide insights into the course of decomposition and indicate that effective management strategies for controlling eutrophication in lakes that harbor $P$. crispus could include the harvesting of this submerged macrophyte before its decomposition.

Acknowledgements We thank the National Natural Science Foundation of China (41303061, 41601086, and 41401329), the Open Foundation of Shandong Provincial Key Laboratory of Water and Soil Conservation and Environmental Protection (stkf201206), the Science 
and Technology Development Plan Project of Shandong Province (2013GSF11701), the Shandong Province Soft Science Research Project (2014rkb01271), the Research Fund for the Doctoral Program of Linyi University (LYDX2013BS063), the Promotion of Research Fund for Excellent Young and Middle-Aged Scientists of Shandong Province (BS2014HZ013), and the Natural Science Foundation of Shandong Province of China (ZR2013CM002).

Open Access This article is distributed under the terms of the Creative Commons Attribution 4.0 International License (http://creativecomm ons.org/licenses/by/4.0/), which permits unrestricted use, distribution, and reproduction in any medium, provided you give appropriate credit to the original author(s) and the source, provide a link to the Creative Commons license, and indicate if changes were made.

\section{References}

Ágoston-Szabó E, Dinka M, Némedi L, Horváth G (2006) Decomposition of Phragmites australis rhizome in a shallow lake. Aquat Bot 85:309-316

Asaeda T, Trung VK, Manatunge J (2000) Modeling the effects of macrophyte growth and decomposition on the nutrient budget in shallow lakes. Aquat Bot 68:217-237

Bakker ES, Donk EV, Declerck SAJ, Helmsing NR, Hidding B, Nolet BA (2010) Effect of macrophyte community composition and nutrient enrichment on plant biomass and algal blooms. Basic Appl Ecol 11:432-439

Bennett EM, Carpenter SR, Caraco NF (2001) Human impact on erodable phosphorus and eutrophication: a global perspective increasing accumulation of phosphorus in soil threatens rivers, lakes, and coastal oceans with eutrophication. Bioscience 51:227-234

Boström B, Andersen JM, Fleischer S, Jansson M (1988) Exchange of phosphorus across the sediment-water interface. Hydrobiologia 170:229-244

Boulton AJ, Boon PI (1991) A review of methodology used to measure leaf litter decomposition in lotic environments: time to turn over an old leaf? Mar Freshw Res 42:1-43

Byren BA, Davies BR (1986) The influence of invertebrates on the breakdown of Potamogeton pectinatus L. in a coastal marina (Zandvlei, South Africa). Hydrobiologia 137:141-151

Carignan R, Kalff J (1980) Phosphorus sources for aquatic weeds: water or sediments? Science 207:987-989

Carpenter SR, Lodge DM (1986) Effects of submersed macrophytes on ecosystem processes. Aquat Bot 26:341-370

Carvalho C, Hepp LU, Palma-Silva C, Albertoni EF (2015) Decomposition of macrophytes in a shallow subtropical lake. Limnol Ecol Manag Inland Waters 53:1-9

Chimney MJ, Pietro KC (2006) Decomposition of macrophyte litter in a subtropical constructed wetland in south Florida (USA). Ecol Eng 27:301-321

Dahroug Z, Santana NF, Pagioro TA (2016) Eichhornia azurea decomposition and the bacterial dynamic: an experimental research. Braz J Microbiol 47:279-286

Gao JQ, Xiong ZT, Zhang JD, Zhang WH, Mba FO (2009) Phosphorus removal from water of eutrophic Lake Donghu by five submerged macrophytes. Desalination 242:193-204

Gessner MO (2000) Breakdown and nutrient dynamics of submerged Phragmites shoots in the littoral zone of a temperate hardwater lake. Aquat Bot 66:9-20

Gonçalves JJF, Santos AM, Esteves FA (2004) The influence of the chemical composition of Typha domingensis and Nymphaea ampla detritus on invertebrate colonization during decomposition in a Brazilian coastal lagoon. Hydrobiologia 527:125-137

Heuschele DJ, Gleason FK (2014) Two stages of dormancy in turions of Potamogeton crispus L. Aquat Bot 119:100-104

Howard-Williams C, Davies BR (1979) The rates of dry matter and nutrient loss from decomposing Potamogeton pectinatus in a brackish south-temperate coastal lake. Freshw Biol 9:13-21

Jarvi HP, Neal C, Williams RJ, Neal M, Wickham HD, Hill LK, Wade AJ, Warwick A, White J (2002) Phosphorus sources, speciation and dynamics in the lowland eutrophic River Kennet, UK. Sci Total Environ 282-283:175

Juston JM, Debusk TA, Grace KA, Jackson SD (2012) A model of phosphorus cycling to explore the role of biomass turnover in submerged aquatic vegetation wetlands for Everglades restoration. Ecol Model 251:135-149

König R, Hepp LU, Santos S (2013) Colonisation of low- and highquality detritus by benthic macroinvertebrates during leaf breakdown in a subtropical stream. Limnol Ecol Manag Inland Waters 45:61-68

Kröger R, Holland MM, Moore MT, Cooper CM (2007) Plant senescence: a mechanism for nutrient release in temperate agricultural wetlands. Environ Pollut 146:114-119

Leoni B, Marti CL, Forasacco E, Mattavelli M, Soler V, Fumagalli P, Imberger J, Rezzonico S, Garibaldi L (2015) The contribution of Potamogeton crispus to the phosphorus budget of an urban shallow lake: Lake Monger, Western Australia. Limnology $17: 175-182$

Li CH, Wang B, Ye C, Ba YX (2014) The release of nitrogen and phosphorus during the decomposition process of submerged macrophyte (Hydrilla verticillata Royle) with different biomass levels. Ecol Eng 70:268-274

Linyi Hydrological Bureau (2016) Statistical bulletin. Linyi Hydrological Bureau, Linyi

Longhi D, Bartoli M, Viaroli P (2008) Decomposition of four macrophytes in wetland sediments: organic matter and nutrient decay and associated benthic processes. Aquat Bot 89:303-310

Menendez M, Hernandez ON, Comin F (2004) Variability of organic matter processing in a Mediterranean coastal lagoon. Int Rev Hydrobiol 89:476-483

Millelindblom C, Tranvik LJ (2003) Antagonism between bacteria and fungi on decomposing aquatic plant litter. Microb Ecol $45: 173-182$

Moss B (1990) Engineering and biological approaches to the restoration from eutrophication of shallow lakes in which aquatic plant communities are important components. Hydrobiologia 200-201:367-377

Olson JS (1963) Energy storage and the balance of producers and decomposers in ecological systems. Ecology 44:322-331

Qin BQ (2009) Lake eutrophication: control countermeasures and recycling exploitation. Ecol Eng 35:1569-1573

Rogers KH, Breen CM (1982) Decomposition of Potamogeton crispus L.: the effects of drying on the pattern of mass and nutrient loss. Aquat Bot 12:1-12

Scheffer M, Jeppesen E (2007) Regime shifts in shallow lakes. Ecosystems 10:1-3

Siong K, Asaeda T (2006) Does calcite encrustation in Chara provide a phosphorus nutrient sink? J Environ Qual 35:490-494

Smock LA, Stoneburner DL (1980) The response of macroinvertebrates to aquatic macrophyte decomposition. Oikos 35:397-403

Sommers LE (1977) Chemical analysis of ecological materials. J Environ Qual 41:494

Titus JE, Pagano AM (2002) Decomposition of litter from submersed macrophytes: the indirect effects of high $\left[\mathrm{CO}_{2}\right]$. Freshw Biol 47:1367-1375

Varga I (2003) Structure and changes of macroinvertebrate community colonizing decomposing rhizome litter of common 
reed at Lake Fertő/Neusiedler See (Hungary). Hydrobiologia 506-509:413-420

Wang L (2015) Regulation of aquatic plants on eutrophic water. Shandong People's Press, Jinan. (In Chinese)

Wang Y, Guo C, Han R (2007) Conditions and tactics of the water environment about the valley of Yi River and Shu River in the aed of Linyi. Water Sci Eng Technol 2007:3 (In Chinese)

Webster JR, Benfield EF (2003) Vascular plant breakdown in freshwater ecosystems. Annu Rev Ecol Syst 17:567-594

Wrubleski DA, Murkin HR, Valk AGVD, Nelson JW (1997) Decomposition of emergent macrophyte roots and rhizomes in a northern prairie marsh. Aquat Bot 58:121-134
Xie Y, Yu D, Ren B (2004) Effects of nitrogen and phosphorus availability on the decomposition of aquatic plants. Aquat Bot 80:29-37

Yoshimura T, Nishioka J, Saito H, Takeda S, Tsuda A, Wells ML (2007) Distributions of particulate and dissolved organic and inorganic phosphorus in North Pacific surface waters. Mar Chem 103:112-121

Yu HC, Ye C, Song XF, Liu J (2010) Comparative analysis of growth and physio-biochemical responses of Hydrilla verticillata to different sediments in freshwater microcosms. Ecol Eng 36:1285-1289 